\title{
Hepatic betaine-homocysteine methyltransferase and methionine synthase activity and intermediates of the methionine cycle are altered by choline supply during negative energy balance in Holstein cows
}

\author{
Danielle N. Coleman, ${ }^{1}$ Mario Vailati-Riboni, ${ }^{1}$ Ahmed A. Elolimy, ${ }^{1}$ Felipe C. Cardoso, ${ }^{1}$ \\ Sandra L. Rodriguez-Zas, ${ }^{1}$ Makoto Miura, ${ }^{2}$ Yuan-Xiang Pan, ${ }^{3,4}$ and Juan J. Loor ${ }^{1,4 *}$ \\ ${ }^{1}$ Department of Animal Sciences, University of Illinois, Urbana 61801 \\ ${ }^{2}$ Ajinomoto Co. Inc., 201-8681 Tokyo, Japan \\ ${ }^{3}$ Department of Food Science and Human Nutrition, University of Illinois, Urbana 61801 \\ ${ }^{4}$ Division of Nutritional Sciences, University of Illinois, Urbana 61801
}

\begin{abstract}
Although choline requirements are unknown, enhanced postruminal supply may decrease liver triacylglycerol (TAG) storage and increase flux through the methionine cycle, helping cows during a negative energy balance (NEB). The objective was to investigate effects of postruminal choline supply during NEB on hepatic activity of betaine-homocysteine methyltransferase (BHMT), methionine synthase (MTR), methionine adenosyltransferase, transcription of enzymes, and metabolite concentrations in the methionine cycle. Ten primiparous rumen-cannulated Holstein cows (158 \pm $24 \mathrm{~d}$ postpartum) were used in a replicated $5 \times 5$ Latin square design with 4 -d treatment periods and $10 \mathrm{~d}$ of recovery $(14 \mathrm{~d} /$ period). Treatments were unrestricted intake with abomasal infusion of water $(\mathrm{A} 0)$, restricted intake (R; $60 \%$ of net energy for lactation requirements to induce NEB) with abomasal infusion of water (R0) or $\mathrm{R}$ plus abomasal infusion of $6.25,12.5$, or $25 \mathrm{~g} / \mathrm{d}$ of choline ion. Liver tissue was collected on d 5 after the infusions ended, blood on d 1 to 5 , and milk on d 1 to 4. Statistical contrasts were A0 versus R0 (CONT1) and tests of linear (L), quadratic (Q), and cubic (C) effects of choline dose. Plasma choline increased with $\mathrm{R}$ (CONT1) and choline (L). Although R decreased milk yield (CONT1), choline increased milk yield and liver phosphatidylcholine (PC), but decreased TAG (L). No differences were observed in plasma $\mathrm{PC}$ or very-lowdensity lipoprotein concentrations with $\mathrm{R}$ or choline. Activity and mRNA abundance of BHMT were greater with $\mathrm{R}$ (CONT1) and increased with choline (L). Although activity of MTR was lower with R (CONT1), it tended to increase with choline $(\mathrm{L})$. No effect of $\mathrm{R}$ was
\end{abstract}

Received December 22, 2018.

Accepted May 10, 2019.

*Corresponding author: jloor@illinois.edu detected for activity of methionine adenosyltransferase, but it changed cubically across dose of choline. Those responses were associated with linear increases in the concentrations of liver tissue $(+13 \%)$ and plasma methionine concentrations. The mRNA abundance of $C P$ T1A, SLC22A5, APOA5, and APOB, genes associated with fatty acid oxidation and lipoprotein metabolism, was upregulated by choline (Q). Overall, enhanced supply of choline during NEB increases hepatic activity of BHMT and MTR to regenerate methionine and PC, partly to help clear TAG. The relevance of these effects during the periparturient period merits further research.

Key words: dairy cow, lactation, methyl donors, onecarbon metabolism

\section{INTRODUCTION}

Dairy cows enter a period of negative energy balance (NEB) when they transition from pregnancy to lactation (i.e., the periparturient period). During this transition, lipid mobilization increases, resulting in greater nonesterified fatty acid (NEFA) uptake by the liver and increased triacylglycerol (TAG) accumulation (Loor et al., 2013b). This accumulation of TAG may be linked to increased NEFA uptake activating sterol regulatory element-binding protein $1 \mathrm{c}$, which recent data indicate could promote transcription of lipogenic genes (Zhu et al., 2019), and the inherently low rate of verylow-density lipoprotein (VLDL) secretion in ruminants (Bauchart et al., 1996). A chronic state of TAG accumulation in the liver can lead to mitochondrial dysfunction and inflammation (Li et al., 2015; Du et al., 2018). To release TAG from the liver it is packaged in VLDL; thus, a way to reduce TAG accumulation may be to stimulate VLDL synthesis and export.

Choline may stimulate VLDL synthesis in the liver through synthesis of phosphatidylcholine (PC), the 
main phospholipid component of VLDL (Vance, 2002). In nonruminants, PC synthesis and VLDL secretion is reduced during choline deficiency, leading to the development of fatty liver (Yao and Vance, 1990; Fast and Vance, 1995). Thus, supplementation of choline during the transition period may help improve VLDL synthesis and reduce liver TAG accumulation. However, studies supplementing rumen-protected choline (RPC) to dairy cows have yielded mixed results, with reductions in hepatic TAG reported in some experiments (Cooke et al., 2007; Zom et al., 2011; Elek et al., 2013), but not in others (Hartwell et al., 2000; Piepenbrink and Overton, 2003; Zhou et al., 2016).

During its metabolism, choline can be oxidized to betaine (Bet), which is used as a methyl donor in the synthesis of Met from homocysteine via the enzyme betaine homocysteine methyltransferase (BHMT; Li and Vance, 2008). Methionine can also be synthesized from homocysteine via 5-methyltetrahydrofolatehomocysteine methyltransferase (MTR). Compared with rats, hepatic BHMT activity was lower and MTR greater in sheep, suggesting a crucial role of the latter in de novo synthesis of Met (Xue and Snoswell, 1985). Despite those general differences, enhanced supply of Bet can increase Met synthesis in liver of sheep, underscoring flexibility of BHMT to substrate availability (Xue and Snoswell, 1985). Because choline may be synthesized endogenously via methyl group donation from Met to S-adenosyl-methionine (SAM) via activity of methionine adenosyltransferase (MAT; Vance et al., 1997), enhanced supply of choline may help increase flux through the Met cycle. This could spare Met so that it can be used for its key roles in protein synthesis, antioxidant production, and methyl group donation (Finkelstein, 1990), rather than making choline. Whether choline supply enhances Met synthesis in dairy cows during NEB, and the mechanisms involved, has not been determined.

Dairy cattle have no known requirement for choline (NRC, 2001). Previous studies with periparturient cows have used approximately $12.5 \mathrm{~g} / \mathrm{d}$ of choline provided as RPC (Zahra et al., 2006; Zom et al., 2011; Zhou et al., 2016), which has been suggested as the optimal amount. Recent work by de Veth et al. (2016) with lactating cows in positive nutrient balance reported that abomasal infusions of choline chloride for $5 \mathrm{~d}$ at 12.5 and $25 \mathrm{~g} / \mathrm{d}$ increased the appearance of choline and its metabolites Bet and phosphocholine in arterial plasma and increased portal flux of choline. In pregnant, nonlactating feed restricted cows (restricted to $31 \%$ of their net energy requirements), increasing choline ion supply from 0 to $25 \mathrm{~g} / \mathrm{d}$ with RPC reduced hepatic TAG concentration linearly. Thus, in the context of physiologic adaptations during periods of NEB, there clearly would be a benefit in determining not only optimal amounts of postruminally delivered choline but also mechanisms in the one-carbon metabolism pathway responsive to choline supply.

The hypothesis for the present study was that incremental postruminal supply of choline during a feed restriction-induced NEB would decrease liver TAG accumulation, increase activity of BHMT, and alter concentrations of intermediates in the Met cycle. Our specific objective was to investigate the effects of postruminal choline supply during a feed restriction-induced NEB on hepatic activity of BHMT, MTR, MAT, transcription of enzymes, and metabolite concentrations in the methionine cycle, and their relationship with liver TAG.

\section{MATERIALS AND METHODS}

\section{Experimental Design and Dietary Treatments}

All procedures involving animals received approval from the Institutional Animal Care and Use Committee at the University of Illinois (protocol no. 16176). Ten primiparous rumen-cannulated Holstein cows (158 \pm 24 postpartum) were used in a $5 \times 5$ replicated Latin square design. Periods were $14 \mathrm{~d}$ in length, with 4 -d treatment periods (d 1-4) and $10 \mathrm{~d}$ of recovery (d 5-14). Treatment periods of $4 \mathrm{~d}$ were chosen based on preliminary observations that suggested concentrations on NEFA and BHB (indicators of NEB) stabilized and began to decrease after $4 \mathrm{~d}$ of feed restriction at $60 \%$ of $\mathrm{NE}_{\mathrm{L}}$ requirements (unpublished data). The 10-d recovery periods were also chosen based on preliminary observations that suggested that milk yield and concentrations of NEFA and BHB had returned to baseline levels $10 \mathrm{~d}$ after feed restriction at $60 \%$ of $\mathrm{NE}_{\mathrm{L}}$ requirements (unpublished data). Additionally, a restriction at $60 \%$ of $\mathrm{NE}_{\mathrm{L}}$ requirements was chosen based on previous work using this restriction model to mimic the periparturient period (Moyes et al., 2010). Treatments in the present study were ad libitum intake with abomasal infusion of water $(\mathbf{A 0})$, restricted intake $\left(\mathbf{R} ; 60 \%\right.$ of $\mathrm{NE}_{\mathrm{L}}$ requirements) with abomasal infusion of water (R0) or R plus abomasal infusion of 6.25 (R6.25), 12.5 (R12.5), or $25 \mathrm{~g} / \mathrm{d}$ of choline ion (R25). The diet was provided as a TMR and formulated to meet NRC (2001) requirements (Table 1). Diets were fed once daily at $0800 \mathrm{~h}$. All cows returned to full feed intake during the 10-d recovery period.

The choline was provided as aqueous choline chloride $(\mathbf{C C}, 70 \%$, Balchem Corporation, New Hampton, NY). The doses of $6.25,12.5$, and $25 \mathrm{~g} / \mathrm{d}$ represent the 
Table 1. Ingredient composition of the diet

\begin{tabular}{|c|c|}
\hline Item & Content \\
\hline \multicolumn{2}{|l|}{ Ingredient, $\%$ of DM } \\
\hline Alfalfa hay & 9.26 \\
\hline Ajipro-L-G3 ${ }^{1}$ & 0.11 \\
\hline Canola meal & 15.15 \\
\hline Corn gluten meal & 4.56 \\
\hline Corn silage & 41.33 \\
\hline Ground shelled corn & 23.24 \\
\hline ProVAAL2 AADvantage ${ }^{2}$ & 0.96 \\
\hline Smartamine $\mathrm{M}^{3}$ & 0.07 \\
\hline Soy hulls & 1.69 \\
\hline Vitamin-mineral mix ${ }^{4}$ & 3.57 \\
\hline Zinpro Availa-Dairy $^{5}$ & 0.06 \\
\hline \multicolumn{2}{|l|}{ Chemical analysis, $\%$ of DM } \\
\hline $\mathrm{CP}$ & 16.00 \\
\hline $\mathrm{ADF}$ & 20.00 \\
\hline $\mathrm{NDF}$ & 18.19 \\
\hline Ether extract & 3.05 \\
\hline $\mathrm{NE}_{\mathrm{L}}, \mathrm{Mcal} / \mathrm{kg}$ & 1.71 \\
\hline
\end{tabular}

${ }^{1}$ Ajinomoto Heartland Inc. (Chicago, IL).

${ }^{2}$ Perdue AgriBusiness (Salisbury, MD).

${ }^{3}$ Adisseo (Alpharetta, GA).

${ }^{4}$ Contained a minimum of $12.5 \% \mathrm{Ca}, 10.4 \% \mathrm{Na}, 2.2 \% \mathrm{Mg}, 8.0 \% \mathrm{~K}$, $0.1 \% \mathrm{~S}, 7.1 \% \mathrm{Se}, 244.5 \mathrm{kIU}$ of vitamin $\mathrm{A} / \mathrm{kg}, 48.9 \mathrm{kIU}$ of vitamin $\mathrm{D}_{3} /$ $\mathrm{kg}$, and $0.922 \mathrm{kIU}$ of vitamin $\mathrm{E} / \mathrm{kg}$.

${ }^{5}$ Zinpro Corporation (Eden Prairie, MN).

amount of choline ion that was supplied postruminally, and were achieved by providing 12.0, 23.9, and $47.9 \mathrm{~g} / \mathrm{d}$ of CC (CC 70\%, Balchem Corporation). Doses above and below the suggested requirement of $12.5 \mathrm{~g} / \mathrm{d}$ of choline allow for the determination of linear and quadratic responses of postruminal choline ion supplementation. Abomasal infusions were accomplished by passing an infusion line through the rumino-omasal orifice into the abomasum by way of the rumen cannula. An infusion line (Tygon tubing, Cole-Parmer, Vernon Hills, IL) fitted with a $60-\mathrm{mL}$ plastic bottle with the bottom removed and with an approximately 8 -cm rubber flange was inserted into the abomasum. The tubing was in place for the duration of the study and was checked daily for proper placement. The infusion apparatus was connected to an external infusion line via a hole in the rumen cannula plug. The internal and external lines were connected by way of quick-disconnect fitting, to allow disconnection for milking. The treatment solutions were provided by mixing the $70 \% \mathrm{CC}$ with deionized tap water and were infused continuously using rotary peristaltic pumps with their corresponding 1,200-mL bag (Sentinel Enteral Feeding Pump, Alcor Scientific Inc., Smithfield, RI). A daily volume of 3,600 $\mathrm{mL} /$ cow (three 1,200-mL bags/d) was infused during the 4 -d treatment period. Infusions were initiated after cows returned from the $0400 \mathrm{~h}$ milking on $\mathrm{d} 1$, and were ended on the morning of $\mathrm{d} 5$ at the $0400 \mathrm{~h}$ milking. Since the cows were milked 3 times a day $(0400,1200$, and $1930 \mathrm{~h}$ ), a new infusion bag was hooked up after each milking.

\section{Feed and Production Parameter Measurements}

Dry matter of individual feed ingredients was determined weekly and the ration was adjusted accordingly to maintain DM ratios of the ingredients. Weekly samples of ingredients and TMR were frozen at $-20^{\circ} \mathrm{C}$ and composited monthly for analysis by standard wet chemistry techniques at a commercial laboratory (Dairy One, Ithaca, NY).

Body weight was recorded on d 1 after the morning milking, and on d 5 after the morning milking. Milk production was recorded daily, and samples were collected at each milking on d 1 to 4 , and on d 14. Composite samples were prepared each day in proportion to milk yield at each milking and were preserved (800 Broad Spectrum Microtabs II; D \& F Control Systems Inc., San Ramon, CA), and analyzed for contents of fat, protein, SNF, MUN, and SCC in a commercial laboratory (Dairy One). Based on milk sample analysis, FCM was calculated daily as follows: $\mathrm{FCM}=(0.4324 \times \mathrm{kg}$ of milk yield $)+(16.216 \times \mathrm{kg}$ of milk fat) (Hutjens, 2010). The concentration of free choline in milk was measured using a commercial kit (no. KA1662, Abonova, Taipei City, Taiwan) where free choline is oxidized by choline oxidase to Bet and hydrogen peroxide, which reacts with a specific dye to form a pink-colored product. Energy balance (EB) was calculated on d 1 and 5 using NRC equations, as described previously (Moyes et al., 2009).

\section{Blood Collection and Analyses}

Blood was sampled from the coccygeal vein after the morning milking on d 1 to 5 , approximately $3 \mathrm{~h}$ before feeding. Samples were collected into vacutainer tubes containing lithium heparin (BD Vacutainer, BD and Co., Franklin Lakes, NJ) and placed on ice. Plasma was obtained by centrifugation at $2,000 \times g$ for $15 \mathrm{~min}$ at $4^{\circ} \mathrm{C}$ and aliquots stored at $-80^{\circ} \mathrm{C}$ until further analysis. Plasma concentrations of BHB were analyzed using a commercial kit (no. 700190, Cayman Chemical, Ann Arbor, MI) and plasma NEFA as described by Johnson and Peters (1993). Concentrations of free choline, VLDL (no. K615-100 and KK613-100, respectively; Biovision Inc., Milpitas, CA), and PC (No. 10009926; Cayman Chemical) in plasma were quantified using commercial kits. Plasma concentrations of AA and AA derivatives were measured on d 5 using an ultra-performance liquid chromatography-MS (Waters, Milford, MA) with the derivatization method (AccQ-Tag Derivatization) provided by Waters. 


\section{Liver Biopsy and Tissue Analysis}

Liver biopsies were conducted on the morning of $\mathrm{d}$ 5 after infusions were ended using a similar technique described previously (Khan et al., 2014; Vailati Riboni et al., 2015). Briefly, the skin was shaved and disinfected, and the skin and body wall were anesthetized with $7 \mathrm{~mL}$ of $2 \%$ lidocaine $\mathrm{HCl}$ (VetOne, Boise, ID). A stab incision was made through the skin in the right 11th intercostal space, through which an 18-gauge by 10.2-cm bone marrow probe (Monoject-8881-247087, Medtronic, Minneapolis, MN) was inserted into the liver and used to obtain approximately $2 \mathrm{~g}$ (wet weight) of liver. No more than 3 separate penetrations with the biopsy probe were performed. Samples were snap frozen in liquid nitrogen and subsequently stored at $-80^{\circ} \mathrm{C}$.

Liver TAG was measured as described by Zhou et al. (2016) and Batistel et al. (2017). Total RNA was extracted from liver tissue using the miRNeasy mini kit (no. 217004, Qiagen, Hilden, Germany). The NanoDrop ND-1000 spectrophotometer (Nano-Drop Technologies, Wilmington, DE) was used to measure the concentration of RNA, whereas the quality of RNA was evaluated using the Agilent Bioanalyzer system (Agilent 2100 Bioanalyzer, Agilent Technologies, Santa Clara, CA). All samples had an RNA integrity number greater than 7 . The quantitative PCR was performed as described previously (Osorio et al., 2014), and full details of the primer design and evaluation and the quantitative PCR performance and primer information are included in the Supplemental Materials and Supplemental Tables S1 and S2 (https://doi.org/10.3168/ jds.2018-16204). Activities of BHMT and MTR were measured as described previously (Zhou et al., 2017; Batistel et al., 2019). Activity of MAT was measured using a commercial kit (no. IK00401, Arthus Biosystems, LLC, Richmond, CA). Protein of enzyme assay samples was measured via the Bradford assay (no. 500-0205, Bio-Rad Laboratories Inc., Hercules, CA). Liver PC content was analyzed using a commercial kit (no. ab83377, Abcam, Cambridge, United Kingdom). This kit uses an enzyme-coupled reaction to hydrolyze PC and release choline, which subsequently oxidizes an OxiRed probe to generate absorbance.

Approximately $150 \mathrm{mg}$ of frozen tissue was extracted for metabolomics analysis using the 2-step protocol described by Wu et al. (2008). Targeted metabolomics [liquid chromatography (LC)-MS] was performed to quantify 4 metabolites related to one-carbon metabolism: homocysteine, SAM, S-5'-adenosyl-homocysteine (SAH), and Met. Samples were analyzed with the 5500 QTRAP LC/MS/MS system (Sciex, Framingham,
MA) in the Metabolomics Laboratory of the Roy J. Carver Biotechnology Center, University of Illinois at Urbana-Champaign. Details of the system and analysis are provided in the Supplemental File, and the multiple reaction monitoring information used for quantification is in Supplemental Table S3 (https://doi.org/10.3168/ jds.2018-16204).

\section{Statistical Analyses}

Data were analyzed as a replicated $5 \times 5$ Latin square with repeated measures of day, when needed, using the MIXED procedure of SAS 9.4 (SAS Institute Inc., Cary, NC).

The model tested the random effects of square and cow within square, and the fixed effects period, treatment, day, and the interaction of treatment $x$ day. Covariance structures compared were compound symmetry, autoregressive order 1, autoregressive heterogeneous order 1, unstructured, and Toeplitz. The compound symmetry structure was used based on the corrected Akaike information criterion. The KenwardRoger degrees of freedom approximation was used to determine the denominator degrees of freedom for tests of fixed effects. The CONTRAST statement of SAS was used to perform 4 orthogonal contrasts: CONT1 $=\mathrm{A} 0$ compared with $\mathrm{R} 0$, and the linear, quadratic, and cubic effects of R0, R6.25, R12.5, and R25. Contrast coefficients were adjusted using the IML procedure to reflect uneven spacing of treatments. Significance was set at $P$ $\leq 0.05$, and tendencies at $P \leq 0.10$. When a polynomial contrast was significant or tended to be significant, equations for the trends were calculated. Pearson correlation coefficients between dependent variables in $R$ cows were calculated using PROC CORR of SAS. The correlations were used to assess the relationship between liver TAG and key metabolites and components of Met and choline metabolism during $\mathrm{R}$. The variables used were liver TAG, Met and PC, plasma free choline, PC, VLDL, and Met, milk free choline, and hepatic activity of BHMT, MTR, and MAT.

Variables were assessed for normality of distribution using the Shapiro-Wilk test. The mRNA abundance data were $\log _{2}$-scale transformed to fit normal distribution of residuals. Tables and graphs contain the $\log _{2}$ back-transformed means that resulted from the statistical analysis. Least squares means and standard errors were determined using the LSMEANS statement of SAS and least squares means separation between time points was performed using the PDIFF statement. When treatment $\times$ day interactions were significant, the SLICE option was used to separate means. 
Table 2. Least squares means and associated pooled SEM for BW and production responses in Holstein cows $(\mathrm{n}=10 /$ treatment $)$ fed 5 different treatments over a period of $4 \mathrm{~d}$ : ad libitum intake with abomasal water infusion, or restricted intake at $60 \%$ of $\mathrm{NE}_{\mathrm{L}}$ requirements with abomasal infusions of $0,6.25,12.5$, or $25 \mathrm{~g} / \mathrm{d}$ of choline $^{1}$

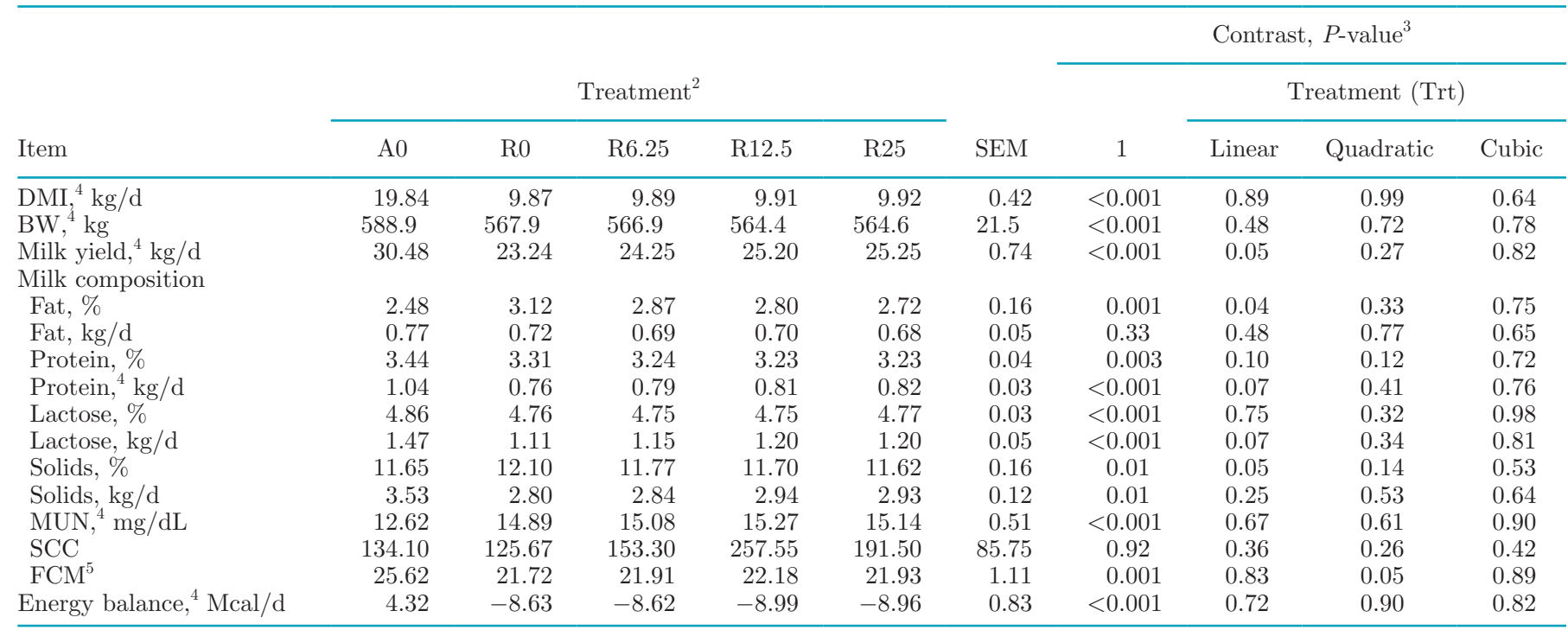

${ }^{1}$ Choline was provided via $70 \%$ aqueous solution of choline chloride (Balchem Corporation, New Hampton, NY) mixed with water.

${ }^{2} \mathrm{~A} 0=$ ad libitum intake, abomasal infusion of water; $\mathrm{R} 0=$ restricted intake, abomasal infusion of water; R6.25 = restricted intake, abomasal infusion of $6.25 \mathrm{~g} / \mathrm{d}$ of choline; R12.5 = restricted intake, abomasal infusion of $12.5 \mathrm{~g} / \mathrm{d}$ of choline; R25 = restricted intake, abomasal infusion of $25 \mathrm{~g} / \mathrm{d}$ of choline.

${ }^{3}$ Contrasts: 1 = A0 compared with R0. Linear, quadratic, and cubic effects of treatments R0, R6.25, R12.5, and R25.

${ }^{4}$ DMI Trt $\times$ day $=0.01 ;$ BW Trt $\times$ day $<0.001 ;$ milk yield Trt $\times$ day $=0.002 ;$ protein yield Trt $\times$ day $=0.003 ;$ MUN Trt $\times$ day $=0.02 ;$ energy balance Trt $\times$ day $=0.04$.

${ }^{5} \mathrm{FCM}=(0.4324 \times \mathrm{kg}$ of milk yield $)+(16.216 \times \mathrm{kg}$ of milk fat $)$.

\section{RESULTS}

\section{Production Responses}

Production results are presented in Table 2. Restriction reduced DMI $(P<0.001$; CONT1 $)$, BW $(P<$ $0.001)$, and $\mathrm{EB}(P<0.001)$. Restriction reduced milk yield $(P<0.001 ;$ CONT1), whereas choline dose had a positive linear effect $(P=0.05 ; \mathrm{Y}=0.07783 \mathrm{X}+$ $23.6325)$. Fat-corrected milk was reduced by $\mathrm{R}(P=$ 0.001 ; CONT1). A positive quadratic effect was also observed FCM $\left(P=0.05 ; \mathrm{Y}=-0.00221 \mathrm{X}^{2}+0.06404 \mathrm{X}\right.$ $+21.72)$, with the R12.5 treatment having the greatest yield. Protein percentage and yield $(P=0.003$ and $P$ $<0.001$, respectively; CONT1), and lactose percentage $(P<0.001)$ decreased with $\mathrm{R}$, whereas fat percentage $(P=0.001)$, solids percentage $(P=0.01)$, and MUN $(P$ $<0.001)$ increased with R (CONT1). A negative linear effect was observed for milk fat percentage $(P=0.04$; $\mathrm{Y}=-0.01431 \mathrm{X}+3.0340)$, whereas a tendency was observed for a negative linear effect for protein percentage $(P=0.10 ; \mathrm{Y}=-0.00178 \mathrm{X}+3.2753)$. Lactose yield also tended to increase linearly $(P=0.07$; $\mathrm{Y}=0.003749 \mathrm{X}+$ 1.1240). Treatment $\times$ day interactions (Supplemental Figures S1 and S2; https://doi.org/10.3168/jds.2018 -16204) were observed for BW $(P<0.001)$, DMI $(P=$
$0.01)$ milk yield $(P=0.002)$, protein yield $(P=0.003)$, MUN $(P=0.02)$, and EB $(P=0.003)$. The interactions for DMI and EB were due to A0 cows having greater intakes and EB compared with cows that were feedrestricted on all days $(P \leq 0.05)$. Interactions for MY and protein yield were observed on d 2 to 4 , with cows in the $\mathrm{R}$ treatments having lower yields compared with A0 cows $(P \leq 0.05)$. The interaction for BW was due to the $\mathrm{R}$ treatments inducing lower BW compared with A0 cows on the morning of $\mathrm{d} 5$ when infusions ended $(P \leq 0.05)$.

\section{Plasma and Milk Metabolites}

The responses of plasma metabolites are presented in Table 3. Concentrations of BHB and NEFA were both increased with $\mathrm{R}(P=0.02, P<0.001$, respectively; CONT1), indicating a NEB was achieved with our feed-restriction model. Additionally, plasma BHB concentrations tended to decrease linearly with choline dose $(P=0.09 ; \mathrm{Y}=-0.00208 \mathrm{X}+0.5008)$. Plasma free choline concentrations increased with $\mathrm{R}(P<0.001$; CONT1) and increased linearly with increasing choline $(P=0.001 ; \mathrm{Y}=0.2058 \mathrm{X}+3.8221)$. No differences were observed in plasma VLDL or PC concentrations 
Table 3. Least squares means and pooled SEM for liver, plasma, and milk biomarker response in Holstein cows ( $\mathrm{n}=10 /$ treatment) fed 5 different treatments over a period of $4 \mathrm{~d}$ : ad libitum intake with abomasal water infusion, or restricted intake at $60 \%$ of $\mathrm{NE}_{\mathrm{L}}$ requirements with abomasal infusions of $0,6.25,12.5$, or $25 \mathrm{~g} / \mathrm{d}$ of choline ${ }^{1}$

\begin{tabular}{|c|c|c|c|c|c|c|c|c|c|c|}
\hline \multirow[b]{2}{*}{ Item $^{2}$} & \multicolumn{5}{|c|}{ Treatment $^{3}$} & \multirow[b]{2}{*}{ SEM } & \multicolumn{4}{|c|}{ Contrast, $P$-value ${ }^{4}$} \\
\hline & $\mathrm{A} 0$ & R0 & $\mathrm{R} 6.25$ & $\mathrm{R} 12.5$ & $\mathrm{R} 25$ & & 1 & Linear & Quadratic & Cubic \\
\hline \multicolumn{11}{|l|}{ Liver } \\
\hline Liver TAG, mg.g of tissue ${ }^{-1}$ & 1.58 & 3.48 & 2.70 & 2.17 & 2.34 & 0.43 & 0.01 & 0.05 & 0.14 & 0.91 \\
\hline Liver PC, mg.g of tissue ${ }^{-1}$ & 0.66 & 0.56 & 0.77 & 0.62 & 0.70 & 0.03 & 0.04 & 0.03 & 0.22 & 0.003 \\
\hline $\mathrm{NEFA},{ }^{5} \mu \mathrm{Eq} \cdot \mathrm{L}^{-1}$ & 120.37 & 365.16 & 328.81 & 332.00 & 340.00 & 22.33 & $<0.001$ & 0.52 & 0.19 & 0.40 \\
\hline Plasma free choline, ${ }^{5} \mu M$ & 2.67 & 3.89 & 5.01 & 6.26 & 8.74 & 0.46 & $<0.001$ & 0.001 & 0.88 & 0.93 \\
\hline Plasma PC, $\mu M$ & 1,621 & 1,686 & 1,623 & 1,682 & 1,690 & 131 & 0.60 & 0.82 & 0.78 & 0.60 \\
\hline Plasma VLDL, $\mu \mathrm{g} \cdot \mathrm{mL}^{-1}$ & 0.26 & 0.25 & 0.31 & 0.28 & 0.25 & 0.03 & 0.84 & 0.52 & 0.15 & 0.29 \\
\hline \multicolumn{11}{|l|}{ Milk } \\
\hline Milk free choline ${ }^{5} \mu M$ & 97.71 & 105.06 & 109.84 & 112.70 & 117.87 & 3.81 & 0.14 & 0.02 & 0.71 & 0.89 \\
\hline
\end{tabular}

${ }^{1}$ Choline was provided via $70 \%$ aqueous solution of choline chloride (Balchem Corporation, New Hampton, NY) mixed with water.

${ }^{2} \mathrm{NEFA}=$ nonesterified fatty acids; $\mathrm{PC}=$ phosphatidylcholine; $\mathrm{TAG}=$ triacylglycerol; $\mathrm{VLDL}=$ very-low-density lipoprotein.

${ }^{3} \mathrm{~A} 0=$ ad libitum intake, abomasal infusion of water; $\mathrm{R} 0=$ restricted intake, abomasal infusion of water; R6.25 = restricted intake, abomasal infusion of $6.25 \mathrm{~g} / \mathrm{d}$ of choline; R12.5 = restricted intake, abomasal infusion of $12.5 \mathrm{~g} / \mathrm{d}$ of choline; R25 = restricted intake, abomasal infusion of $25 \mathrm{~g} / \mathrm{d}$ of choline.

${ }^{4}$ Contrasts: 1 = A0 compared with R0. Linear, quadratic, and cubic effects of treatments R0, R6.25, R12.5, and R25.

${ }^{5}$ NEFA Trt $\times$ day $<0.001$; plasma free choline Trt $\times$ day $<0.001$; milk free choline $\operatorname{Trt} \times$ day $<0.001$.

$(P>0.10)$. In milk, concentrations of free choline also increased linearly with dose of choline $(P=0.02 ; \mathrm{Y}=$ $0.4982 \mathrm{X}+105.61)$.

Treatment $\times$ day effects (Supplemental Figure S3; https://doi.org/10.3168/jds.2018-16204) were observed for plasma NEFA $(P<0.001)$ and free choline $(P<$ $0.001)$, and milk free choline $(P<0.001)$. The interaction for NEFA was due to $\mathrm{R}$ cows having greater concentrations on d 2 to 5 compared with A0 cows ( $P$ $\leq 0.05)$. In plasma, R25 cows had greater concentrations of free choline on d 2 to 5 compared with other treatments $(P \leq 0.05)$. Compared with R6.25, R12.5 cows had greater plasma free choline on d $2(P=0.02)$ and tended to have greater concentrations $(P=0.10)$ on $\mathrm{d} 4$. The R12.5 cows also had greater free choline in plasma on d 2 to 5 when compared with R0 cows $(P$ $\leq 0.05)$. The R6.25 treatment led to greater concentrations than R0 on $\mathrm{d} 3$ and $5(P \leq 0.05)$. The treatment $\times$ day interaction for free choline in milk was mainly due to R25 cows having greater concentrations compared with other treatments on d $2(P \leq 0.05)$, whereas, on d 4, R25 and R12.5 cows had greater concentrations than R6.25 and R0 cows $(P \leq 0.05)$. Plasma concentrations of PC and VLDL were correlated positively on $\mathrm{d} 5$ in $\mathrm{R}$ cows $(\mathrm{r}=0.38 ; P=0.02$; Table 4$)$. The concentrations of free choline in milk and plasma tended to be positively correlated $(\mathrm{r}=0.31 ; P=0.06)$. Plasma free choline was also correlated positively with plasma PC concentrations in $\mathrm{R}$ cows $(\mathrm{r}=0.32 ; P=0.04)$.

\section{Plasma AA}

Amino acid and derivative concentrations are presented in Table 5. The doubling of concentration of 3 -methyl histidine $(P<0.001 ;$ CONT1 $)$ in response to R0 indicated enhanced muscle protein breakdown. Among the EAA, except for concentrations of arginine, phenylalanine, isoleucine, and leucine, all other AA were decreased $(P<0.05$; CONT1) by R0. Similarly, among the NEAA, except for alanine, glutamate, glycine, and serine, all other AA were decreased $(P<$ 0.05 ; CONT1) by R0. Methionine $(P=0.01 ; \mathrm{Y}=$ $0.0155 \mathrm{X}+2.9786)$ and threonine $(P=0.03 ; \mathrm{Y}=$ $0.05720 \mathrm{X}+8.6326)$ increased linearly across choline dose. Plasma serine also changed cubically $(P=0.04$; $\left.\mathrm{Y}=-0.00170 \mathrm{X}^{3}+0.06582 \mathrm{X}^{2}-0.6029 \mathrm{X}+10.9680\right)$. Among AA derivatives, ornithine decreased with R0 $(P<0.001 ;$ CONT1). Additionally, plasma Met was negatively correlated (Table 4 ) with hepatic TAG in R cows $(\mathrm{r}=-0.36 ; P=0.02)$.

\section{Liver Composition and Metabolites}

Liver TAG content (Table 3) was greater with $\mathrm{R}(P$ $=0.01 ; \mathrm{CONT} 1)$. There was linear reduction in TAG content across choline doses $(P=0.05 ; \mathrm{Y}=-0.4197 \mathrm{X}$ +3.1316 ), with the lowest content observed with R12.5. Liver PC content decreased with $\mathrm{R}(P=0.04$; CONT1) and there was a significant cubic effect $(P=0.003$; 
Table 4. Pearson correlation coefficients among hepatic concentrations of triacylglycerol (TAG), phosphatidylcholine (PC), and Met, plasma free choline, very-low-density lipoprotein (VLDL), Met and PC concentrations, milk free choline, and hepatic activity of betaine homocysteine methyltransferase (BHMT), 5-methyltetrahydrofolaare-homocysteine methyltransferase (MTR), and methionine adenosyltransferase (MAT) in Holstein cows fed to $60 \%$ of their $\mathrm{NE}_{\mathrm{L}}$ requirements with abomasal infusions of $0,6.25,12.5$, or $25 \mathrm{~g} / \mathrm{d}$ of choline for $4 \mathrm{~d}^{1}$

\begin{tabular}{|c|c|c|c|c|c|c|c|c|c|c|}
\hline Variable & $\begin{array}{l}\text { Liver } \\
\text { TAG }\end{array}$ & $\begin{array}{l}\text { Plasma free } \\
\text { choline }\end{array}$ & $\begin{array}{l}\text { Milk free } \\
\text { choline }\end{array}$ & $\begin{array}{c}\text { Plasma } \\
\text { PC }\end{array}$ & $\begin{array}{l}\text { Liver } \\
\text { PC }\end{array}$ & $\begin{array}{l}\text { Plasma } \\
\text { VLDL }\end{array}$ & $\begin{array}{l}\text { BHMT } \\
\text { activity }\end{array}$ & $\begin{array}{l}\text { MTR } \\
\text { activity }\end{array}$ & $\begin{array}{l}\text { MAT } \\
\text { activity }\end{array}$ & $\begin{array}{l}\text { Liver } \\
\text { Met }\end{array}$ \\
\hline Plasma free choline & -0.16 & & & & & & & & & \\
\hline Milk free choline & -0.23 & $0.31 \dagger$ & & & & & & & & \\
\hline Liver PC & -0.01 & $0.48^{*}$ & 0.18 & $0.45^{*}$ & & & & & & \\
\hline Plasma VLDL & -0.02 & -0.17 & -0.07 & $0.38^{*}$ & 0.07 & & & & & \\
\hline BHMT activity & $-0.37^{*}$ & $0.42^{*}$ & 0.25 & 0.11 & 0.20 & -0.25 & & & & \\
\hline Liver Met & -0.19 & 0.17 & -0.16 & $0.31 \dagger$ & 0.12 & 0.06 & -0.05 & -0.04 & -0.08 & \\
\hline Plasma Met & $-0.36^{*}$ & 0.18 & -0.03 & 0.05 & -0.01 & 0.004 & 0.18 & 0.26 & -0.11 & $0.36^{*}$ \\
\hline
\end{tabular}

${ }^{1}$ Choline was provided via $70 \%$ aqueous solution of choline chloride (Balchem Corporation, New Hampton, NY) mixed with water.

$* P \leq 0.05 ; \dagger P \leq 0.10$.

$\left.\mathrm{Y}=0.000198 \mathrm{X}^{3}-0.00737 \mathrm{X}^{2}+0.06653 \mathrm{X}-0.5564\right)$. 6$)$. Concentrations of hepatic Met tended $(P=0.08$; Of the 4 metabolites measured in liver tissue via LC- CONT1) to decrease in liver tissue with R0 versus A0, MS, homocysteine, and SAM were undetectable (Table but increased linearly across choline dose $(P=0.05 ; \mathrm{Y}$

Table 5. Least squares means and pooled SEM for plasma AA concentrations in Holstein cows $(\mathrm{n}=10 /$ treatment $)$ fed 5 different treatments over a period of $4 \mathrm{~d}$ : ad libitum intake with abomasal water infusion, or restricted intake at $60 \%$ of $\mathrm{NE}_{\mathrm{L}}$ requirements with abomasal infusions of $0,6.25,12.5$, or $25 \mathrm{~g} / \mathrm{d}$ of choline ${ }^{1}$

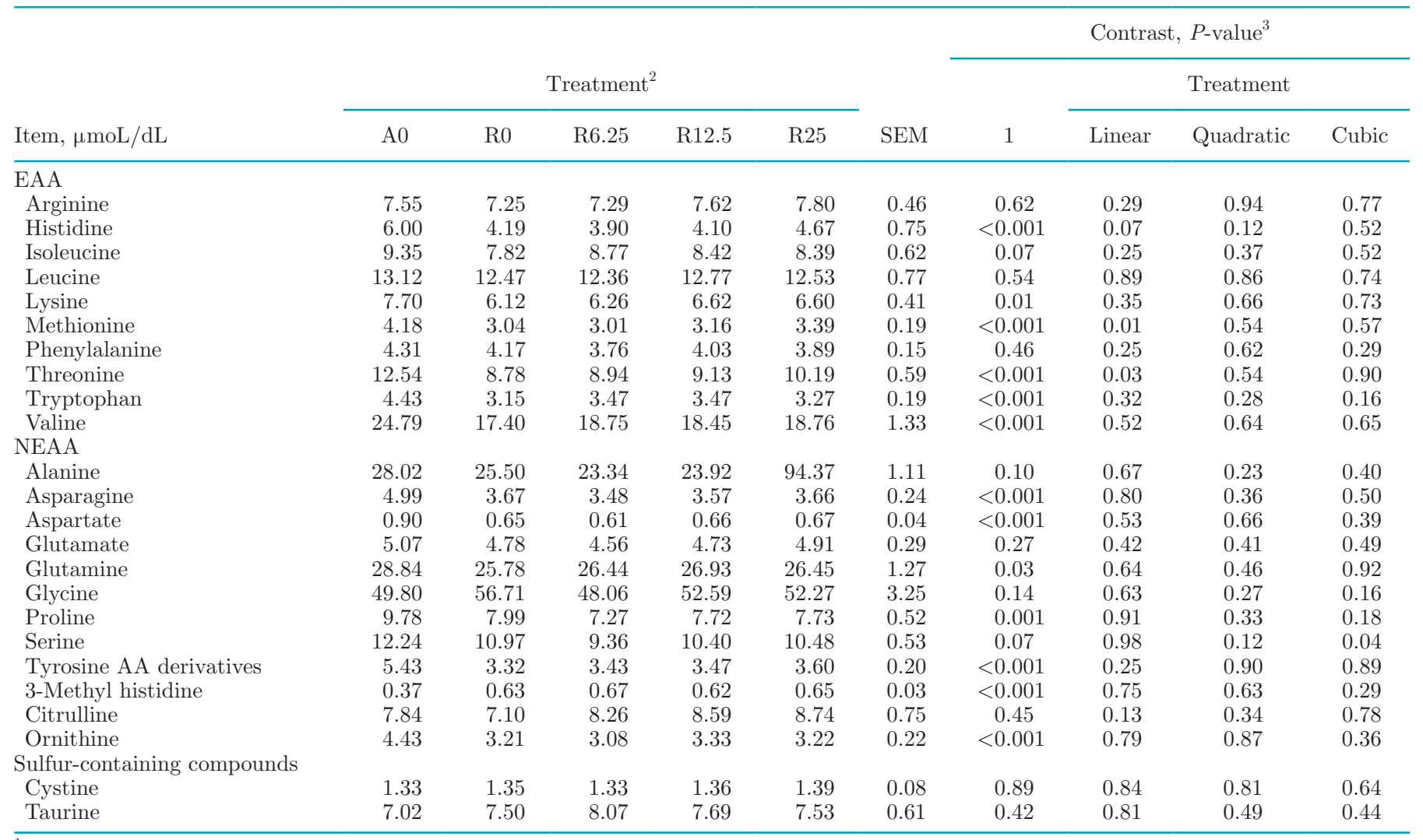

${ }^{1}$ Choline was provided via $70 \%$ aqueous solution of choline chloride (Balchem Corporation, New Hampton, NY) mixed with water.

${ }^{2} \mathrm{~A} 0=\mathrm{ad}$ libitum intake, abomasal infusion of water; $\mathrm{R} 0=$ restricted intake, abomasal infusion of water; R6.25 = restricted intake, abomasal infusion of $6.25 \mathrm{~g} / \mathrm{d}$ of choline; R12.5 = restricted intake, abomasal infusion of $12.5 \mathrm{~g} / \mathrm{d}$ of choline; R25 = restricted intake, abomasal infusion of $25 \mathrm{~g} / \mathrm{d}$ of choline.

${ }^{3}$ Contrasts: 1 = A0 compared with R0. Linear, quadratic, and cubic effects of treatments R0, R6.25, R12.5, and R25. 
$=1.4399 \mathrm{X}+315.13)$. Hepatic SAH also changed cubically $\left(P=0.01 ; \mathrm{Y}=0.0786 \mathrm{X}^{3}-2.6855 \mathrm{X}^{2}+20.518 \mathrm{X}\right.$ $+294.26)$; of the treatments the concentration of SAH was lowest for R12.5. The hepatic concentration of Met was also positively correlated (Table 4) with plasma Met concentrations $(\mathrm{r}=0.36 ; P=0.03)$ and tended to be positively correlated with plasma $\mathrm{PC}$ in $\mathrm{R}$ cows $(\mathrm{r}=0.31 ; P=0.07)$. Hepatic PC concentrations were correlated positively with plasma free choline $(\mathrm{r}=0.48$; $P=0.002)$ and plasma $\mathrm{PC}(\mathrm{r}=0.45 ; P=0.01)$.

\section{Methionine and Choline Metabolism Pathway}

Activity of BHMT, MTR, and MAT are in Table 6 and hepatic mRNA abundance for genes in the Met and choline metabolism pathways are presented in Table 7. Activity of BHMT was greater with $\mathrm{R}(P$ $=0.02$ CONT1) and increased linearly with choline $(P=0.05 ; \mathrm{Y}=0.06312 \mathrm{X}+7.8368)$. Abundance of $B H M T$ was greater with R0 versus A0 $(P=0.0001$; CONT1). A positive quadratic effect was also observed for $B H M T$ abundance $\left(P=0.002 ; \mathrm{Y}=-0.00021 \mathrm{X}^{2}+\right.$ $0.01066 \mathrm{X}+1.0256)$. Abundance of the isoform BHMT2 was greater with $\mathrm{R}(P=0.003 ; \mathrm{CONT} 1)$. Activity of MTR decreased with $\mathrm{R}(P=0.02 ; \mathrm{CONT} 1)$ but tended to increase linearly with choline supply $(P=0.07 ; \mathrm{Y}=$ $0.4141 \mathrm{X}+58.9313)$. No difference was observed in the mRNA abundance of MTR $(P>0.10)$. The activity of MAT changed cubically across choline dose $(P=0.04$;
$\left.\mathrm{Y}=-0.02925 \mathrm{X}^{3}+1.0164 \mathrm{X}^{2}-8.1334 \mathrm{X}+107.34\right)$, decreasing from $\mathrm{R} 0$ to $\mathrm{R} 6.25$, then increasing with $\mathrm{R} 12.5$ and then decreasing again to R25. The abundance of methionionine adenosyltransferase 1A (MAT1A) was lower with $\mathrm{R}(P=0.02$; CONT1). In contrast, methionine adenosyltransferase 2A (MAT2A) was greater with $\mathrm{R}(P<0.001 ; \mathrm{CONT1})$. The mRNA abundance of phosphatidylethanolamine methyltransferase (PEMT) tended to be decreased by $\mathrm{R}$ relative to $\mathrm{A} 0(P=0.09)$.

Hepatic TAG concentration was correlated negatively (Table 4) with activity of BHMT $(\mathrm{r}=-0.37 ; P=0.02)$ and MTR ( $\mathrm{r}=-0.42 ; P=0.01)$. Activity of BHMT was also positively correlated with plasma free choline concentration $(\mathrm{r}=0.42 ; P=0.01)$. The activities of MTR and MAT were negatively correlated with each other $(\mathrm{r}=0.47 ; P=0.003)$.

\section{Cytidine Diphosphate-Choline Pathway}

The mRNA abundance results for the cytidine diphosphate (CDP)-choline pathway are reported in Table 7. The abundance of choline/ethanolamine phosphotransferase 1 (CEPT1) was lower with $\mathrm{R}(P=0.01$; CONT1). A negative quadratic effect $(P=0.001)$ was also observed for CEPT1. Abundance of choline kinase $\mathrm{B}(C H K B)$ increased with $\mathrm{R}(P=0.02$; CONT1). The abundance of phosphate cytidyltransferase 1 , choline, $\mathrm{b}$ $(P C Y$ T1B $)$ tended to be increased with $\mathrm{R}(P=0.09$; CONT1).

Table 6. Least squares means and pooled SEM for betaine homocysteine methyltransferase (BHMT), methionine adenosyltransferase (MAT), and 5-methyltetrahydrofolate-homocysteine methyltransferase (MTR) activity and liver concentrations on metabolites (measured via liquid chromatography-MS) in the methionine cycle in Holstein cows $(\mathrm{n}=10 /$ treatment $)$ fed 5 different treatments over a period of 4 d: ad libitum intake with abomasal water infusion, or restricted intake at $60 \%$ of $\mathrm{NE}_{\mathrm{L}}$ requirements with abomasal infusions of $0,6.25,12.5$, or $25 \mathrm{~g} / \mathrm{d}$ of choline $^{1}$

\begin{tabular}{|c|c|c|c|c|c|c|c|c|c|c|}
\hline Item & \multicolumn{5}{|c|}{ Treatment $^{2}$} & SEM & \multicolumn{4}{|c|}{ Contrast, $P$-value ${ }^{3}$} \\
\hline \multicolumn{11}{|l|}{$\begin{array}{l}\text { Enzyme activity, nmol of } \\
\text { product } \cdot \mathrm{h}^{-1} \cdot \mathrm{mg} \text { of protein }\end{array}$} \\
\hline ВHMT & 5.28 & 7.40 & 8.51 & 9.09 & 9.12 & 0.64 & 0.02 & 0.05 & 0.21 & 0.94 \\
\hline \multicolumn{11}{|l|}{ Metabolite, $\mathrm{ng} \cdot \mathrm{mg}$ of protein $^{-1}$} \\
\hline Methionine & 386.61 & 327.55 & 324.87 & 330.93 & 354.64 & 24.23 & 0.08 & 0.05 & 0.73 & 0.95 \\
\hline Homocysteine & $\mathrm{ND}^{4}$ & ND & ND & ND & ND & - & - & - & - & - \\
\hline S-5'-adenosyl-homocysteine & 304.26 & 294.26 & 334.69 & 271.69 & 318.42 & 20.08 & 0.67 & 0.71 & 0.50 & 0.01 \\
\hline S-5'-adenosyl-methionine & ND & ND & ND & ND & ND & — & - & - & - & - \\
\hline
\end{tabular}

${ }^{1}$ Choline was provided via $70 \%$ aqueous solution of choline chloride (Balchem Corporation, New Hampton, NY) mixed with water.

${ }^{2} \mathrm{~A} 0=$ ad libitum intake, abomasal infusion of water; $\mathrm{R} 0=$ restricted intake, abomasal infusion of water; R6.25 = restricted intake, abomasal infusion of $6.25 \mathrm{~g} / \mathrm{d}$ of choline; R12.5 = restricted intake, abomasal infusion of $12.5 \mathrm{~g} / \mathrm{d}$ of choline; R25 = restricted intake, abomasal infusion of $25 \mathrm{~g} / \mathrm{d}$ of choline.

${ }^{3}$ Contrasts: 1 = A0 compared with R0. Linear, quadratic, and cubic effects of treatments R0, R6.25, R12.5, and R25.

${ }^{4} \mathrm{ND}=$ not detectable. 


\section{Lipid Metabolism}

The effects of $\mathrm{R}$ and choline supplementation on abundance of genes related to lipid metabolism are presented in Table 7. Restriction increased the abundance (CONT1) of apolipoprotein A5 (APOA5; $P=0.001$ ), CD36 molecule $(C D 36 ; P<0.001)$, cAMP responsive element binding protein $1(C R E B 1 ; P=0.004)$, solute carrier family 22 member 5 (SLC22A5, choline transporter; $P<0.001$ ), and tended to increase abundance of carnitine palmitoyltransferase $1 \mathrm{~A}(C P T 1 A ; P=0.08)$. In contrast, $\mathrm{R}$ decreased abundance of apolipoprotein B $(A P O B ; P=0.002)$ and fatty acid binding protein 1 (FABP1; $P<0.001)$. A positive linear effect was observed for the abundance of APOA5 $(P=0.02$; Y $=$ $0.01006 \mathrm{X}+1.0381)$. Increasing dose of choline induced

Table 7. Least squares means and pooled SEM for hepatic mRNA abundance in Holstein cows ( $\mathrm{n}=10 /$ treatment) fed 5 different treatments over a period of $4 \mathrm{~d}$ : ad libitum intake with abomasal water infusion, or restricted intake at $60 \%$ of $\mathrm{NE}_{\mathrm{L}}$ requirements with abomasal infusions of $0,6.25,12.5$, or $25 \mathrm{~g} / \mathrm{d}$ of choline ${ }^{1}$

\begin{tabular}{|c|c|c|c|c|c|c|c|c|c|c|}
\hline \multirow[b]{3}{*}{ Item $^{2}$} & \multirow{2}{*}{\multicolumn{5}{|c|}{ Treatment $^{3}$}} & \multirow[b]{3}{*}{ SEM } & \multicolumn{4}{|c|}{ Contrast, $P$-value ${ }^{4}$} \\
\hline & & & & & & & \multirow[b]{2}{*}{1} & \multicolumn{3}{|c|}{ Treatment } \\
\hline & $\mathrm{A} 0$ & $\mathrm{R} 0$ & $\mathrm{R} 6.25$ & $\mathrm{R} 12.5$ & $\mathrm{R} 25$ & & & Linear & Quadratic & Cubic \\
\hline \multicolumn{11}{|c|}{$\begin{array}{l}\text { Methionine and choline } \\
\text { metabolism, log-2 } \\
\text { backtransformed }\end{array}$} \\
\hline BHMT & 0.62 & 1.02 & 1.08 & 1.09 & 1.13 & 0.05 & 0.001 & 0.003 & 0.002 & 0.91 \\
\hline ВНMT2 & 0.33 & 0.50 & 0.55 & 0.52 & 0.53 & 0.15 & 0.003 & 0.64 & 0.70 & 0.56 \\
\hline$M A T 1 A$ & 1.33 & 1.07 & 1.15 & 1.13 & 1.05 & 0.09 & 0.02 & 0.87 & 0.33 & 0.49 \\
\hline MAT2A & 0.71 & 0.99 & 1.13 & 1.08 & 1.08 & 0.06 & $<0.001$ & 0.43 & 0.19 & 0.21 \\
\hline MTHFR & 1.17 & 1.18 & 1.06 & 1.04 & 1.13 & 0.10 & 0.92 & 0.74 & 0.13 & 0.82 \\
\hline$M T R$ & 1.05 & 1.13 & 1.14 & 1.09 & 1.12 & 0.06 & 0.19 & 0.80 & 0.64 & 0.46 \\
\hline$P E M T$ & 0.82 & 0.72 & 0.76 & 0.78 & 0.78 & 0.06 & 0.09 & 0.34 & 0.43 & 0.87 \\
\hline$S A H H$ & 1.14 & 1.22 & 1.30 & 1.35 & 1.26 & 0.04 & 0.33 & 0.78 & 0.13 & 0.93 \\
\hline \multicolumn{11}{|c|}{$\begin{array}{l}\mathrm{CDP}^{5} \text {-choline pathway, } \\
\text { log-2 backtransformed }\end{array}$} \\
\hline CEPT1 & 1.25 & 1.10 & 1.05 & 1.05 & 1.02 & 0.05 & 0.01 & 0.14 & 0.62 & 0.70 \\
\hline$C H K A$ & 0.87 & 0.98 & 0.85 & 0.87 & 0.89 & 0.09 & 0.16 & 0.44 & 0.14 & 0.42 \\
\hline$C H K B$ & 0.54 & 0.60 & 0.57 & 0.57 & 0.58 & 0.02 & 0.02 & 0.45 & 0.17 & 0.64 \\
\hline PCYT1A & 0.87 & 0.97 & 1.09 & 0.96 & 0.98 & 0.05 & 0.15 & 0.61 & 0.53 & 0.07 \\
\hline$P C Y T 1 B$ & 1.07 & 1.26 & 1.04 & 1.16 & 1.06 & 0.10 & 0.09 & 0.15 & 0.46 & 0.09 \\
\hline \multicolumn{11}{|c|}{$\begin{array}{l}\text { Lipid metabolism, log-2 } \\
\text { backtransformed }\end{array}$} \\
\hline$A C A D V L$ & 0.95 & 1.05 & 1.12 & 1.06 & 1.12 & 0.06 & 0.10 & 0.36 & 0.48 & 0.95 \\
\hline$A C O X 1$ & 1.17 & 1.04 & 1.05 & 1.05 & 1.07 & 0.08 & 0.11 & 0.64 & 0.91 & 0.83 \\
\hline$A P O A 5$ & 0.71 & 0.97 & 1.15 & 1.18 & 1.19 & 0.08 & 0.001 & 0.02 & 0.09 & 0.51 \\
\hline$A P O B$ & 1.08 & 0.96 & 1.04 & 1.04 & 1.00 & 0.04 & 0.02 & 0.60 & 0.05 & 0.51 \\
\hline$C D 36$ & 0.65 & 1.23 & 0.97 & 1.05 & 1.17 & 0.09 & $<0.001$ & 0.88 & 0.01 & 0.11 \\
\hline CPT1A & 0.78 & 0.91 & 0.99 & 1.00 & 0.96 & 0.04 & 0.01 & 0.43 & 0.09 & 0.76 \\
\hline CREB1 & 0.89 & 1.05 & 0.96 & 0.96 & 1.02 & 0.04 & 0.004 & 0.75 & 0.04 & 0.55 \\
\hline$F A B P 1$ & 1.39 & 0.81 & 0.90 & 0.88 & 0.88 & 0.07 & $<0.001$ & 0.52 & 0.51 & 0.56 \\
\hline MTTP & 1.21 & 1.11 & 1.11 & 1.00 & 1.07 & 0.05 & 0.12 & 0.27 & 0.15 & 0.16 \\
\hline PPARA & 1.02 & 1.06 & 1.10 & 1.10 & 1.10 & 0.06 & 0.91 & 0.55 & 0.58 & 0.69 \\
\hline SLC22A 5 & 0.53 & 0.87 & 1.03 & 1.10 & 1.01 & 0.09 & $<0.001$ & 0.13 & 0.01 & 0.62 \\
\hline
\end{tabular}

${ }^{1}$ Choline was provided via $70 \%$ aqueous solution of choline chloride (Balchem Corporation, New Hampton, NY) mixed with water.

${ }^{2} A C A D V L=$ acyl-CoA dehydrogenase very long chain; $A C O X 1=$ acyl-CoA oxidase $1 ; A P O A 5=$ apolipoprotein A5; $A P O B=$ apolipoprotein B; $B H M T=$ betaine homocysteine methyltransferase; $B H M T 2=$ betaine homocysteine methyltransferase $2 ; C D 36=$ CD 36 molecule; $C D O 1$ = cysteine dioxygenase; $C E P T 1=$ choline/ethanolamine phosphotransferase $1 ; C H K A=$ choline kinase A; $C H K B=$ choline kinase $\mathrm{B} ; C P T 1 A$ $=$ carnitine palmitoyltransferase $1 \mathrm{~A} ; C R E B 1=\mathrm{cAMP}$ responsive element binding protein $1 ; F A B P 1=$ fatty acid binding protein $1 ; M A T 1 A$ $=$ methionine adenosyltransferase $1 \mathrm{~A} ; M A T 2 A=$ methionine adenosyltransferase $2 \mathrm{~A} ; M T H F R=$ methylenetetrahydrofolate reductase; $M T R$ = 5-methyltetrahydrofolate-homocysteine methyltransferase; $M T T P=$ microsomal triglyceride transfer protein; $P C Y T 1 A=$ phosphate cytidylyltransferase 1, choline, a; $P C Y T 1 B=$ phosphate cytidylyltransferase 1, choline, b; $P E M T=$ phosphatidylethanolamine methyltransferase; $P P A R A=$ peroxisome proliferator activated receptor $\alpha ; S A H H=$ S-adenosylhomocysteine hydrolase; $S L C 22 A 5=$ solute carrier family 22 member 5 .

${ }^{3} \mathrm{~A} 0=$ ad libitum intake, abomasal infusion of water; $\mathrm{R} 0=$ restricted intake, abomasal infusion of water; R6.25 = restricted intake, abomasal infusion of $6.25 \mathrm{~g} / \mathrm{d}$ of choline; R12.5 = restricted intake, abomasal infusion of $12.5 \mathrm{~g} / \mathrm{d}$ of choline; R25 = restricted intake, abomasal infusion of $25 \mathrm{~g} / \mathrm{d}$ of choline.

${ }^{4}$ Contrasts: $1=$ A0 compared with R0; Treatment $=$ R0 compared with the average of the 3 treatments $(6.25,12.5$, and 25 g/d of choline). Linear and quadratic effects of treatments R0, R6.25, R12.5, and R25.

${ }^{5} \mathrm{CDP}=$ cytidine diphosphate. 
a positive quadratic effect $\left(P=0.05 ; \mathrm{Y}=-0.00067 \mathrm{X}^{2}\right.$ $+0.01856 \mathrm{X}+0.9615)$ in $A P O B$, whereas there was a quadratic tendency for $C P T 1 A$ to increase across dose $\left(P=0.09 ; \mathrm{Y}=-0.00067 \mathrm{X}^{2}+0.01968 \mathrm{X}+0.9171\right) . \mathrm{A}$ quadratic effect was observed for $C D 36(P=0.01 ; \mathrm{Y}=$ $\left.0.001660 \mathrm{X}^{2}-0.04225 \mathrm{X}+1.1947\right)$; abundance decreased from R0 to R6.25, but then increased with R12.5 and R25. A quadratic effect was observed for CREB1 ( $P$ $\left.=0.04 ; \mathrm{Y}=0.000823 \mathrm{X}^{2}-0.02223 \mathrm{X}+1.0469\right)$ where abundance decreased from R0 to R6.25 but increased with greater doses. Last, a quadratic effect $(P=0.01$; $\left.\mathrm{Y}=-0.00202 \mathrm{X}^{2}+0.05910 \mathrm{X}+0.8712\right)$ was observed for SLC22A5 and was greatest in R12.5 cows.

\section{DISCUSSION}

\section{Energy Balance Biomarkers and Milk Production}

In the present study, the drop in BW, EB, and milk yield coupled with greater plasma concentrations of NEFA and BHB with R indicated that our feed-restriction model successfully induced a NEB. While choline supply increased milk yield in the present study, other studies with abomasal infusions of choline have been inconsistent; Sharma and Erdman (1989) observed increases in milk yield when 40 and $50 \mathrm{~g} / \mathrm{d}$ of choline was infused for 3 -week periods, whereas infusions of 12.5 and $25 \mathrm{~g} / \mathrm{d}$ for $5 \mathrm{~d}$ by de Veth et al. (2016) did not alter milk yield. Inconsistencies in results among studies might be related to differences in length of infusion, as well as the use of feed restriction in the present study. However, perhaps the most relevant data in the context of experimental design is that of de Veth et al. (2016), where no differences in milk yield or composition were detected when delivering 12.5 or $25 \mathrm{~g} / \mathrm{d}$ of choline postruminally to cows in late lactation. In the present study, DMI is eliminated as the driver of increasing milk yield, due to the lack of differences in DMI between the restricted diets.

One explanation for the increase in milk yield with increasing choline could be Bet production. Betaine is produced when choline is oxidized in the mitochondria and can act as an osmolyte (Eklund et al., 2005). Several studies with dairy cattle have observed increases in milk yield with rumen-protected Bet supplementation (Wang et al., 2010; Peterson et al., 2012). Postruminal delivery of choline was previously observed to increase the concentration of Bet in milk (de Veth et al., 2016) suggesting that Bet concentrations in milk likely increased in the present study as well. The fact that we detected a linear increase in hepatic Bet concentration with increasing choline supply (reported in a companion paper; Coleman et al., 2019) supports the idea that Bet production was increased with enhanced postruminal choline supply. Hence, an increase in Bet may have led to an increase in milk yield through its function as an osmolyte, pulling water to the mammary gland. A second potential explanation for the increase in milk yield could be the tendency for greater lactose yield with increasing choline dose. Lactose serves as an osmoregulator that controls milk volume (Kuhn et al., 1980). Thus, an increase in lactose synthesis might have promoted increased milk yield. Further work is needed to understand the mechanisms by which choline (or its metabolites) might alter lactose synthesis.

The tendency for increasing milk protein yield with increasing choline dose was due to the increase in milk production with choline. The fact that R12.5 had the highest FCM yield compared with R6.25 and R25 was also likely due to the greater milk fat yield with R12.5 compared with the other 2 choline treatments. Additionally, previous work by Sharma and Erdman (1989) indicated that increases in milk fat with abomasal infusions of choline may be associated with increased NEFA mobilization and utilization for milk fat. Although plasma NEFA was not different between choline doses, it is possible that more NEFA were going toward milk fat with R12.5, driving the increase in milk fat and FCM yields.

\section{Methionine and Choline Metabolism}

The significant increase in plasma and milk free choline concentrations across doses of choline, and the positive relationship between them, indicated that our abomasal infusions were successful at delivering choline postruminally. The data agree with de Veth et al. (2016) when they infused 12.5 and $25 \mathrm{~g} / \mathrm{d}$ to cows in late lactation. The decrease in liver TAG content with choline is in accordance with previous work where RPC was fed for longer periods of time (Cooke et al., 2007; Zom et al., 2011; Elek et al., 2013). While liver TAG content decreased with choline in the present study, the mechanism behind this reduction is unclear. Choline is used to synthesize PC in the liver, which can be incorporated into VLDL and exported (Vance, 2002), potentially helping decrease TAG storage in the liver. While choline increased liver PC, the greatest increase was with R6.25 and not R12.5. However, this agrees with previous work in periparturient cows where liver PC increased with $12.5 \mathrm{~g} / \mathrm{d}$ of choline relative to controls (Zhou et al., 2017). In nonruminants, the changes in liver PC are associated with changes in the export of VLDL (Yao and Vance, 1990); however, concentrations of plasma VLDL were not altered by choline in the present study. Because $12.5 \mathrm{~g} / \mathrm{d}$ resulted in the greatest reduction in liver TAG, these changes along with the lack of differences in plasma PC suggest that enhanced 
secretion of VLDL was not the main mechanism by which choline decreased liver TAG. This idea is supported by the lack of difference in the abundance of hepatic PEMT, the enzyme that converts phosphatidylethanolamine to PC (Zeisel, 1992), and is further indication that this was not the avenue by which liver $\mathrm{PC}$ increased.

The CDP-choline pathway can also generate PC. Choline kinases convert choline to phosphocholine to begin the pathway (Fagone and Jackowski, 2013). In the present study, the lack of difference in the abundance of $C H K A$ and $C H K B$ with choline supply suggested that choline did not enhance the production of phosphocholine. This is in contrast to the study by de Veth et al. (2016), where abomasal infusions of choline increased plasma phosphocholine concentrations; however, those cows were not in NEB. The next step in the pathway is the conversion of phosphocholine to CDP-choline by phosphate cytidylyltransferase enzymes (Fagone and Jackowski, 2013). The CDP-choline is then used to synthesize PC via CEPT1. Changes in PCYT1A and $P C Y T 1 B$ were inconsistent; abundance of $P C Y T 1 B$ tended to decrease with $\mathrm{R}$, whereas $P C Y T 1 A$ did not change. The mRNA abundance of these 2 enzymes also did not change significantly in the same pattern with increasing choline dose, and abundance of PCYT1A was similar in R0, R12.5, and R25 cows. Thus, this suggests that CDP-choline production might have been enhanced with $\mathrm{R}$ via $P C Y T 1 B$, but the effects of choline on CDP-choline production are not clear.

The decrease in CEPT1 abundance with $\mathrm{R}$ suggests that PC synthesis from phosphocholine may not have been increased with R. However, these changes do not agree with the increase in liver PC observed with increased choline supply, which suggests that the changes in transcription may not have resulted in corresponding changes in translation or activity. These results also contrast with previous work in periparturient cows where hepatic expression of CHKA, PCYT1A, and $P C Y T 1 B$ increased with RPC supplementation at 12.5 $\mathrm{g} / \mathrm{d}$ of choline (Zhou et al., 2017). A recent in vitro study revealed that supplementing bovine hepatocytes with choline increased mRNA abundance of CEPT1, CHKA, CHKB, and PCYT1A (Zhou et al., 2018). The differences in the mRNA changes between the present and aforementioned studies could be related to the longer supplementation period by Zhou et al. $(2017$; $-21 \mathrm{~d}$ through $30 \mathrm{~d}$ around parturition) or the use of cells in the in vitro study.

The role of Met in dairy cows during NEB, not only for milk protein synthesis, but also for antioxidant production and as a methyl donor, was well established in nonruminants decades ago (Finkelstein, 1990). Me- thionine can be used to synthesize choline via methyl group donation from Met to SAM (Vance et al., 1997). Compared with nonruminants, the amount of choline synthesized from Met is relatively high in ruminants because degradation of choline in the rumen limits its bioavailability (Snoswell and Xue, 1987). In turn, choline can provide methyl groups for the synthesis of Met from homocysteine via BHMT (Li and Vance, 2008). However, in ruminants the activity of BHMT is lower than that of MTR (Xue and Snoswell, 1985). In the present study, the increase in mRNA abundance and activity of BHMT along with liver and plasma Met content underscored an important role for BHMT and choline for de novo synthesis of Met during periods of NEB. As such, cows that are unable to consume enough Met from the diet during periods of NEB could in part alleviate a shortfall of this EAA via the BHMT reaction. The tendency for greater activity of MTR in response to increasing supply of choline agrees with in vitro mRNA abundance of MTR generated in hepatocytes (Chandler and White, 2017; Zhou et al., 2018). Together, those data indicate a role of choline in increasing Met synthesis via MTR. Additionally, the increases in liver and plasma Met with increasing choline supply provide further evidence that Met synthesis was increased by choline during a feed restriction-induced NEB. Overall, our data seem to underscore the importance of Met synthesis during times of NEB and suggest a greater reliance on BHMT during those times.

Methionine adenosyltransferases convert Met to SAM (Corrales et al., 2002). Although the activity of MAT in the present study was greater than the activities of BHMT and MTR, it is in line with previous work in sheep by Radcliffe and Egan (1978). The fact that R0 had the greatest MAT activity is in accordance with previous work where fasting was observed to increase the activity of MAT in the liver of mice (Sakata et al., 2005) and sheep (Radcliffe and Egan, 1978). In nonruminant liver, increased Met concentrations lead to greater SAM production via MAT (Corrales et al., 2002). However, the linear increase in hepatic Met with increasing choline dose was associated with a cubic, rather than linear, change in MAT activity with activity being greatest in R12.5 cows, rather than R25. In the study by Radcliffe and Egan (1978), abomasal infusions of Met decreased MAT activity, suggesting that beyond a certain threshold increasing availability of cellular Met depresses MAT activity in ruminants. Thus, the fact that R25 cows had the lowest MAT activity could be related to them having the greatest hepatic Met concentrations. Additionally, homocysteine can be synthesized from SAH via SAHH. Although liver homocysteine could not be detected in the present study, 
suggesting rapid utilization, liver SAH concentration was lowest in R12.5 cows, suggesting a greater production of homocysteine.

\section{Lipid Metabolism}

When NEFA are taken up by the liver via CD36, they are preferentially stored in hepatocytes (Loor et al., 2013a). Thus, increases in the abundance of CD36 with $\mathrm{R}$ provide a link between NEFA uptake and TAG accumulation in the present study. Although PPARA was not altered, the changes in APOA5, SLC22A5, and $C P T 1 A$ suggest greater PPAR $\alpha$ activity in response to choline supply during $\mathrm{R}$. These genes have been established as PPAR $\alpha$ targets in nonruminant tissues, and evidence indicates that they are also targets in ruminants (Bionaz et al., 2013). Because the activity of CPT1A is partly regulated at a transcriptional level in nonruminants (Nakamura et al., 2014), the greater abundance of CPT1A (a gene involved in fatty acid oxidation) suggested an increase in mitochondrial $\beta$-oxidation. The increase in abundance of SLC22A5 mRNA with choline is in agreement with previous work in periparturient cows (Goselink et al., 2013). This transporter is associated with carnitine transport into cells, which has been observed to reduce liver TAG in dairy cattle through stimulation of FA oxidation (Carlson et al., 2007).

The mechanism behind these changes may be related to increased availability of methyl donors in the liver with enhanced choline supply. For instance, in the liver of mice increased flux through BHMT has been associated with altered DNA methylation of the promoter region of PPARA, resulting in increased abundance of CPT1A (Wang et al., 2013). In human hepatocytes, supplementation of choline induced a similar effect, upregulating $C P T 1 A$ and downregulating fatty acid synthase (Zhu et al., 2014). Thus, even though PPARA abundance was not altered, increased synthesis of Met could have led to changes in DNA methylation, which may have mediated the increase in CPT1A. This potential mechanism provides a possible link for the negative relationship between BHMT and MTR activity and liver TAG. Further work is needed to fully elucidate the mechanisms behind the potential effects of choline on fatty acid metabolism in ruminants.

The protein APOA5 is associated with VLDL and high-density lipoproteins, and (at least in nonruminants) is involved in lowering hepatic TAG content (Ress et al., 2011). While apolipoproteins are not closely regulated at the transcriptional level, the linear increase in $A P O A 5$ in response to increasing choline supply during $\mathrm{R}$ may be associated with the reduction in liver TAG. In addition, the quadratic increase in
$A P O B$ (also related to VLDL production) with choline supply suggests an increase in VLDL assembly. Similar changes have been reported with long-term RPC supplementation (Goselink et al., 2013). Despite these molecular changes, choline supply did not alter plasma concentrations of VLDL and PC, or abundance of microsomal triglyceride transfer protein $(M T T P)$. Therefore, it is unclear whether VLDL export was increased with enhance choline supply during our feed restriction-induced NEB. Previous work with bovine neonatal hepatocytes incubated with NEFA revealed an increase in VLDL with increasing choline dose, but this was not associated with a change in MTTP (Chandler and White, 2017). Thus, despite a lack of effect on MTTP abundance, this suggests that VLDL export might have increased. Additionally, it should be noted that the lack of changes in plasma PC and VLDL in response to choline supply could have been due utilization by other tissues (e.g., the mammary gland); PC is one of the main choline metabolites in bovine milk (Artegoitia et al., 2014) and long-chain fatty acids in milk can be obtained from VLDL (Palmquist and Mattos, 1978; Loor et al., 2002).

\section{Limitations}

While the use of a feed restriction-induced NEB provides the ability to mimic the DMI-induced NEB of the periparturient period, such a model does not fully mimic the NEB experienced by peripartal cows. This is because the DMI-induced NEB associated with the peripartal period lasts longer than $4 \mathrm{~d}$ and is also associated with the physical and hormonal stress of calving. Compared with cows in early lactation, use of cows in late lactation in the present study may also be a limitation due to the differences in milk production and metabolism. Last, although this study provides critical information on how different doses of choline alter milk production and hepatic metabolism, it was not designed to collect data on portal circulation and flux. Thus, to fully understand how different doses of choline alter metabolism, collection of such data should be considered in future studies.

\section{CONCLUSIONS}

Postruminal choline supply beyond the suggested $12.5 \mathrm{~g} / \mathrm{d}$ during a feed restriction-induced NEB benefits milk production and liver fatty acid metabolism. While liver PC content and hepatic apoprotein mRNA abundance increased, no statistical changes were observed in plasma VLDL or PC. Transcriptional changes also suggest a role of choline in increasing fatty acid oxidation to further reduce liver TAG accumulation during 
a NEB. Beyond lipid metabolism, adaptations in the activity of BHMT and MTR are important to maintain Met synthesis during a NEB, especially when the supply of choline increases. This observation underscores the importance of choline supply when dairy cows experience periods of NEB.

\section{ACKNOWLEDGMENTS}

Ahmed A. Elolimy is a recipient of a $\mathrm{PhD}$ fellowship from Missions Sector, Higher Education Ministry, Egypt, to perform his $\mathrm{PhD}$ studies at the University of Illinois (Urbana).

\section{REFERENCES}

Artegoitia, V. M., J. L. Middleton, F. M. Harte, S. R. Campagna, and M. J. de Veth. 2014. Choline and choline metabolite patterns and associations in blood and milk during lactation in dairy cows. PLoS One 9:e103412.

Batistel, F., A. S. Alharthi, R. R. C. Yambao, A. A. Elolimy, Y. X. Pan, C. Parys, and J. J. Loor. 2019. Methionine supply during late-gestation triggers offspring sex-specific divergent changes in metabolic and epigenetic signatures in bovine placenta. J. Nutr. 149:6-17. https://doi.org/10.1093/jn/nxy240.

Batistel, F., J. M. Arroyo, A. Bellingeri, L. Wang, B. Saremi, C. Parys, E. Trevisi, F. C. Cardoso, and J. J. Loor. 2017. Ethyl-cellulose rumen-protected methionine enhances performance during the periparturient period and early lactation in Holstein dairy cows. J. Dairy Sci. 100:7455-7467. https://doi.org/10.3168/jds.2017-12689.

Bauchart, D., D. Gruffat, and D. Durand. 1996. Lipid absorption and hepatic metabolism in ruminants. Proc. Nutr. Soc. 55(1B):39-47.

Bionaz, M., S. Chen, M. J. Khan, and J. J. Loor. 2013. Functional role of PPARs in ruminants: Potential targets for fine-tuning metabolism during growth and lactation. PPAR Res. 2013:684159.

Carlson, D. B., J. W. McFadden, A. D'Angelo, J. C. Woodworth, and J. K. Drackley. 2007. Dietary L-carnitine affects periparturient nutrient metabolism and lactation in multiparous cows. J. Dairy Sci. 90:3422-3441.

Chandler, T. L., and H. M. White. 2017. Choline and methionine differentially alter methyl carbon metabolism in bovine neonatal hepatocytes. PLoS One 12:e0171080.

Coleman, D. N., A. Alharthi, V. Lopreiato, E. Trevisi, M. Miura, Y. X. Pan, and J. J. Loor. 2019. Choline supply during negative energy balance alters hepatic cystathionine $\beta$-synthase activity, intermediates of the methionine cycle and transsulfuration pathway, and liver function in Holstein cows. J. Dairy Sci. 102:8319-8331. https://doi.org/10.3168/jds.2019-16406.

Cooke, R. F., N. Silva Del Rio, D. Z. Caraviello, S. J. Bertics, M. H. Ramos, and R. R. Grummer. 2007. Supplemental choline for prevention and alleviation of fatty liver in dairy cattle. J. Dairy Sci. 90:2413-2418.

Corrales, F. J., I. Pérez-Mato, M. M. Sánchez del Pino, F. l. Ruiz, C. Castro, E. R. García-Trevijano, U. Latasa, M. L. MartínezChantar, A. Martínez-Cruz, M. A. Avila, and J. M. Mato. 2002. Regulation of mammalian liver methionine adenosyltransferase. J. Nutr. 132:2377S-2381S.

de Veth, M. J., V. M. Artegoitia, S. R. Campagna, H. Lapierre, F. Harte, and C. L. Girard. 2016. Choline absorption and evaluation of bioavailability markers when supplementing choline to lactating dairy cows. J. Dairy Sci. 99:9732-9744.

Du, X., T. Shen, H. Wang, X. Qin, D. Xing, Q. Ye, Z. Shi, Z. Fang, Y. Zhu, Y. Yang, Z. Peng, C. Zhao, B. Lv, X. Li, G. Liu, and X. Li. 2018. Adaptations of hepatic lipid metabolism and mitochondria in dairy cows with mild fatty liver. J. Dairy Sci. 101:9544-9558.
Eklund, M., E. Bauer, J. Wamatu, and R. Mosenthin. 2005. Potential nutritional and physiological functions of betaine in livestock. Nutr. Res. Rev. 18:31-48.

Elek, P., T. Gaal, and F. Husveth. 2013. Influence of rumen-protected choline on liver composition and blood variables indicating energy balance in periparturient dairy cows. Acta Vet. Hung. 61:59-70.

Fagone, P., and S. Jackowski. 2013. Phosphatidylcholine and the CDPcholine cycle. Biochim. Biophys. Acta 1831:523-532.

Fast, D. G., and D. E. Vance. 1995. Nascent VLDL phospholipid composition is altered when phosphatidylcholine biosynthesis is inhibited: Evidence for a novel mechanism that regulates VLDL secretion. Biochim. Biophys. Acta 1258:159-168.

Finkelstein, J. D. 1990. Methionine metabolism in mammals. J. Nutr. Biochem. 1:228-237.

Goselink, R. M. A., J. van Baal, H. C. A. Widjaja, R. A. Dekker, R. L. G. Zom, M. J. de Veth, and A. M. van Vuuren. 2013. Effect of rumen-protected choline supplementation on liver and adipose gene expression during the transition period in dairy cattle. J. Dairy Sci. 96:1102-1116.

Hartwell, J. R., M. J. Cecava, and S. S. Donkin. 2000. Impact of dietary rumen undegradable protein and rumen-protected choline on intake, peripartum liver triacylglyceride, plasma metabolites and milk production in transition dairy cows. J. Dairy Sci. 83:29072917.

Hutjens, M. F. 2010. Benchmarking your feed efficiency, feed costs and income over feed cost. Pages 3-10 in Proc. Western Canadian Dairy Seminar. Red Deer, Alberta Canada, University of Alberta, Edmonton, Alberta, Canada.

Johnson, M. M., and J. Peters. 1993. Technical note: An improved method to quantify nonesterified fatty acids in bovine plasma. J. Anim. Sci. 71:753-756.

Khan, M. J., C. B. Jacometo, D. E. Graugnard, M. N. Corrêa, E. Schmitt, F. Cardoso, and J. J. Loor. 2014. Overfeeding dairy cattle during late-pregnancy alters hepatic PPAR $\alpha$-regulated pathways including hepatokines: Impact on metabolism and peripheral insulin sensitivity. Gene Regul. Syst. Bio. 8:97-111. https://doi.org/10 .4137/GRSB.S14116

Kuhn, N. J., D. T. Carrick, and C. J. Wilde. 1980. Lactose synthesis: The possibilities of regulation. J. Dairy Sci. 63:328-336.

Li, X., W. Huang, J. Gu, X. Du, L. Lei, X. Yuan, G. Sun, Z. Wang, X. Li, and G. Liu. 2015. SREBP-1c overactivates ROS-mediated hepatic NF- $\kappa B$ inflammatory pathway in dairy cows with fatty liver. Cell. Signal. 27:2099-2109.

Li, Z., and D. E. Vance. 2008. Phosphatidylcholine and choline homeostasis. J. Lipid Res. 49:1187-1194.

Loor, J. J., A. B. Bandara, and J. H. Herbein. 2002. Characterization of 18:1 and 18:2 isomers produced during microbial biohydrogenation of unsaturated fatty acids from canola and soya bean oil in the rumen of lactating cows. J. Anim. Physiol. Anim. Nutr. (Berl.) $86: 422-432$.

Loor, J. J., G. Bertoni, A. Hosseini, J. R. Roche, and E. Trevisi. 2013a. Functional welfare - Using biochemical and molecular technologies to understand better the welfare state of peripartal dairy cattle. Anim. Prod. Sci. 53:931-953. https://doi.org/10.1071/AN12344.

Loor, J. J., M. Bionaz, and J. K. Drackley. 2013b. Systems physiology in dairy cattle: Nutritional genomics and beyond. Annu. Rev. Anim. Biosci. 1:365-392. https://doi.org/10.1146/annurev-animal $-031412-103728$

Moyes, K. M., J. K. Drackley, D. E. Morin, and J. J. Loor. 2010. Greater expression of TLR2, TLR4, and IL6 due to negative energy balance is associated with lower expression of HLA-DRA and HLA-A in bovine blood neutrophils after intramammary mastitis challenge with Streptococcus uberis. Funct. Integr. Genomics 10:53-61. https://doi.org/10.1007/s10142-009-0154-7.

Moyes, K. M., J. K. Drackley, J. L. Salak-Johnson, D. E. Morin, J. C. Hope, and J. J. Loor. 2009. Dietary-induced negative energy balance has minimal effects on innate immunity during a Streptococcus uberis mastitis challenge in dairy cows during midlactation. J. Dairy Sci. 92:4301-4316. 
Nakamura, M. T., B. E. Yudell, and J. J. Loor. 2014. Regulation of energy metabolism by long-chain fatty acids. Prog. Lipid Res. 53:124-144.

NRC. 2001. Nutrient Requirements of Dairy Cattle: 7th rev. ed. The National Academies Press, Washington, DC.

Osorio, J. S., P. Ji, J. K. Drackley, D. Luchini, and J. J. Loor. 2014. Smartamine M and MetaSmart supplementation during the peripartal period alter hepatic expression of gene networks in 1-carbon metabolism, inflammation, oxidative stress, and the growth hormone-insulin-like growth factor 1 axis pathways. J. Dairy Sci. 97:7451-7464.

Palmquist, D. L., and W. Mattos. 1978. Turnover of lipoproteins and transfer to milk fat of dietary (1-carbon-14) linoleic acid in lactating cows. J. Dairy Sci. 61:561-565.

Peterson, S. E., P. Rezamand, J. E. Williams, W. Price, M. Chahine, and M. A. McGuire. 2012. Effects of dietary betaine on milk yield and milk composition of mid-lactation Holstein dairy cows. J. Dairy Sci. 95:6557-6562.

Piepenbrink, M. S., and T. R. Overton. 2003. Liver metabolism and production of cows fed increasing amounts of rumen-protected choline during the periparturient period. J. Dairy Sci. 86:1722-1733.

Radcliffe, B. C., and A. Egan. 1978. The effect of diet and of methionine loading on activity of enzymes in the transulfuration pathway in sheep. Aust. J. Biol. Sci. 31:105-114.

Ress, C., A. R. Moschen, N. Sausgruber, A. Tschoner, I. Graziadei, H. Weiss, W. Schgoer, C. F. Ebenbichler, R. J. Konrad, J. R. Patsch, H. Tilg, and S. Kaser. 2011. The role of apolipoprotein A5 in nonalcoholic fatty liver disease. Gut 60:985-991.

Sakata, S. F., S. Okumura, K. Matsuda, Y. Horikawa, M. Maeda, K. Kawasaki, J. Y. Chou, and N. Tamaki. 2005. Effect of fasting on methionine adenosyltransferase expression and the methionine cycle in the mouse liver. J. Nutr. Sci. Vitaminol. (Tokyo) 51:118-123.

Sharma, B. K., and R. A. Erdman. 1989. Effects of dietary and abomasally infused choline on milk production responses of lactating dairy cows. J. Nutr. 119:248-254.

Snoswell, A. M., and G.-P. Xue. 1987. Methyl group metabolism in sheep. Comp. Biochem. Physiol. B 88:383-394.

Vailati Riboni, M., S. Meier, N. V. Priest, C. R. Burke, J. K. Kay, S. McDougall, M. D. Mitchell, C. G. Walker, M. Crookenden, A. Heiser, J. R. Roche, and J. J. Loor. 2015. Adipose and liver gene expression profiles in response to treatment with a nonsteroidal antiinflammatory drug after calving in grazing dairy cows. J. Dairy Sci. 98:3079-3085.

Vance, D. E., C. J. Walkey, and Z. Cui. 1997. Phosphatidylethanolamine N-methyltransferase from liver. Biochim. Biophys. Acta 1348:142-150.

Vance, J. E. 2002. Assembly and secretion of lipoproteins. Pages 505526 in New Compr. Biochem. Vol. 36. Elsevier.

Wang, C., Q. Liu, W. Z. Yang, J. Wu, W. W. Zhang, P. Zhang, K. H. Dong, and Y. X. Huang. 2010. Effects of betaine supplementation on rumen fermentation, lactation performance, feed digest- ibilities and plasma characteristics in dairy cows. J. Agric. Sci. 148:487-495.

Wang, L., L. Chen, Y. Tan, J. Wei, Y. Chang, T. Jin, and H. Zhu. 2013. Betaine supplement alleviates hepatic triglyceride accumulation of apolipoprotein E deficient mice via reducing methylation of peroxisomal proliferator-activated receptor alpha promoter. Lipids Health Dis. 12:34.

Wu, H., A. D. Southam, A. Hines, and M. R. Viant. 2008. Highthroughput tissue extraction protocol for NMR- and MS-based metabolomics. Anal. Biochem. 372:204-212.

Xue, G. P., and A. M. Snoswell. 1985. Comparative studies on the methionine synthesis in sheep and rat tissues. Comp. Biochem. Physiol. B 80:489-494.

Yao, Z. M., and D. E. Vance. 1990. Reduction in VLDL, but not HDL, in plasma of rats deficient in choline. Biochem. Cell Biol. 68:552-558.

Zahra, L. C., T. F. Duffield, K. E. Leslie, T. R. Overton, D. Putnam, and S. J. LeBlanc. 2006. Effects of rumen-protected choline and monensin on milk production and metabolism of periparturient dairy cows. J. Dairy Sci. 89:4808-4818.

Zeisel, S. H. 1992. Choline: An important nutrient in brain development, liver function and carcinogenesis. J. Am. Coll. Nutr. 11:473481.

Zhou, Y. F., Z. Zhou, F. Batistel, I. Martinez-Cortés, R. T. Pate, D. L. Luchini, and J. J. Loor. 2018. Methionine and choline supply alter transmethylation, transsulfuration, and cytidine 5'-diphosphocholine pathways to different extents in isolated primary liver cells from dairy cows. J. Dairy Sci. 101:11384-11395. https://doi .org/10.3168/jds.2017-14236.

Zhou, Z., T. A. Garrow, X. Dong, D. N. Luchini, and J. J. Loor. 2017. Hepatic activity and transcription of betaine-homocysteine methyltransferase, methionine synthase, and cystathionine synthase in periparturient dairy cows are altered to different extents by supply of methionine and choline. J. Nutr. 147:11-19.

Zhou, Z., M. Vailati-Riboni, E. Trevisi, J. K. Drackley, D. N. Luchini, and J. J. Loor. 2016. Better postpartal performance in dairy cows supplemented with rumen-protected methionine compared with choline during the peripartal period. J. Dairy Sci. 99:8716-8732.

Zhu, J., Y. Wu, Q. Tang, Y. Leng, and W. Cai. 2014. The effects of choline on hepatic lipid metabolism, mitochondrial function and antioxidative status in human hepatic C3A cells exposed to excessive energy substrates. Nutrients 6:2552.

Zhu, Y., G. Liu, X. Du, Z. Shi, M. Jin, X. Sha, X. Li, Z. Wang, and X. Li. 2019. Expression patterns of hepatic genes involved in lipid metabolism in cows with subclinical or clinical ketosis. J. Dairy Sci. 102:1725-1735

Zom, R. L. G., J. van Baal, R. M. A. Goselink, J. A. Bakker, M. J. de Veth, and A. M. van Vuuren. 2011. Effect of rumen-protected choline on performance, blood metabolites, and hepatic triacylglycerols of periparturient dairy cattle. J. Dairy Sci. 94:4016-4027. 